\title{
PRESCRIPTION PATTERNS OF ANTIHYPERTENSIVE DRUGS AND ADHERENCE TO JNC VII GUIDELINES IN A TERTIARY CARE HOSPITAL IN NORTH INDIA
}

\author{
BAJAJ J.K ${ }^{1}$, SOOD $M^{1 *}{ }^{*}$, SINGH S.J. ${ }^{2}$ AND JERATH P. ${ }^{3}$ \\ 1Department of Pharmacology, Punjab Institute of Medical Sciences \\ 2Medical Officer, PCMS, Civil Hospital, Jalandhar, Punjab \\ ${ }^{3}$ Consultant Pathologist, Jerath Path Labs, Jalandhar, Punjab \\ *Corresponding Author: Email- msood11@gmail.com
}

Received: December 15, 2011; Accepted: January 15, 2012

\begin{abstract}
-
Introduction

Hypertension is a chronic illness associated with high morbidity \& mortality. A large number of antihypertensive drugs alone or in various combinations are available and physicians need to choose the most appropriate drug for a particular patient. The standard treatment guidelines and drug utilization studies at regular intervals help physicians to prescribe drugs rationally. The present study was conducted to analyze the prescription patterns of antihypertensive drugs and adherence to JNC VII guidelines in a North Indian tertiary care hospital.

Methods

Drug utilization data of 500 hypertensive patients, attending medicine Out Patient Department of Punjab Institute of Medical Sciences Hospital from October 2010 to March 2011 was collected from 24 hour hospital pharmacy. Following groups of anti hypertensive drugs were analyzed; Angiotensin converting enzyme inhibitors (ACE inhibitors), Angiotensin Receptor Blockers (ARBs), Beta Blockers, Calcium Channel Blockers (CCBs), Diuretics, Alpha Adrenergic Blockers and Central Sympatholytics. Patients suffering from essential hypertension with or without other co-morbid conditions were included in the study. Frequency and proportion of prescribing different groups of anti hypertensive drugs as monotherapy or combination therapy and prescription of fixed drug combinations (FDCs) was analyzed.

Results

The most frequently prescribed antihypertensive drugs were diuretics followed by ARBs, Beta Blockers, CCB's and ACE inhibitors. $42.6 \%$ received monotherapy and $57.4 \%$ received combination therapy. $41.6 \%$ patients received fixed drug combinations. The prescription pattern was found to be in accordance with JNC VII guidelines.
\end{abstract}

Key Words- Antihypertensives, drug utilization, ACE inhibitors, ARBs, Diuretics, JNC VII

Citation: Bajaj J.K., et al. (2012) Prescription patterns of antihypertensive drugs and adherence to JNC VII Guidelines in a tertiary care hospital in north India. International Journal of Medical and Clinical Research, ISSN:0976-5530 \& E-ISSN:0976-5549, Volume 3, Issue 2, pp.$115-117$

Copyright: Copyright@2012: Bajaj J.K., et al. This is an open-access article distributed under the terms of the Creative Commons Attribution License, which permits unrestricted use, distribution, and reproduction in any medium, provided the original author and source are credited.

\section{Introduction}

Hypertension is a public health problem causing $4.5 \%$ of global disease burden. Prevalence is estimated to increase further from $26.4 \%$ in 2000 to $29.2 \%$ in 2025 worldwide [1]. Raised blood pressure is an important risk factor for cardiovascular disease [2]. Hypertension related deaths constitute $1 / 3 \mathrm{rd}$ of global mortality cases [3]. Sufficient scientific evidence exists to suggest that such adverse outcomes can be prevented by lowering blood pressure effectively $[4,5]$. Therefore, once hypertension is diagnosed, starting rational antihypertensive therapy on long term basis along with regular follow up is immensely important.
A wide range of antihypertensive drugs belonging to different pharmacological classes are available such as Angiotensin Converting Enzyme inhibitors, Beta Blockers, Angiotensin Receptor Blockers, Calcium Channel Blockers, Diuretics, Alpha adrenergic blockers and central sympatholytics. Choice of drugs for a particular patient changes at short intervals because of factors like efficacy, side effects, cost and development of newer drugs [6]. Recommendations of various expert groups regarding choice of drugs are available as treatment guidelines to reduce practice variability, cost and improve rational pharmacotherapy. Implementation of these guidelines has been shown to be effective in raising quality of antihypertensive therapy [7]. 
The 7th report of Joint National Committee on prevention, detection, evaluation \& treatment of high blood pressure (JNC VII) recommends the use of thiazide type diuretics alone or in combination with drugs from other classes in uncomplicated essential hypertension. Presence of certain high risk conditions is indication for initiating therapy with other drug classes like ACE inhibitors, ARBs, Beta blockers or CCBs. For $\mathrm{BP}>20 / 10 \mathrm{~mm}$ of $\mathrm{Hg}$ above goal $\mathrm{BP}$, combination of two agents is recommended with one of them usually being a thiazide diuretic [8].

In such a scenario it is necessary to survey prescription patterns as a component of medical audit for monitoring, evaluation \& necessary modifications in prescribing practices to achieve rational and cost effective medical care [9]. Keeping all these facts in mind, the present study was designed to analyze the prescribing patterns of anti hypertensive drugs \& adherence to JNC VII guidelines in 500 hypertensive patients in a tertiary care hospital in North India.

\section{Material and Methods}

The study was approved by institutional ethics committee. Drug utilization data was collected from the 24 hour hospital pharmacy of Punjab Institute of Medical Sciences, Jalandhar for a period of 6 months from October 2010 to March 2011. Prescriptions of hypertensive patients with diabetes mellitus and bronchial asthma as co morbidities were also included. Age and sex of patients was recorded. Mean age along with SE was calculated. $Z$ test was used to calculate the $P$ value of age difference between two sexes. Depending on age patients were divided into 3 groups ( $<40$ years of age, $40-60$ years \& $>60$ years of age). Antihypertensive drugs were divided into following 7 categories: ACE inhibitors, ARB's, Beta blockers, CCB's, Diuretics, Alpha adrenergic blockers and Central sympatholytics. Fixed drug combinations were counted separately. The components of FDCs were counted in their respective groups as well. Adherence to JNC VII guidelines was studied by assuming that drugs recommended as first line should be the most frequently prescribed ones with highest utilization.

\section{Results}

As shown in Table 1, 210 patients (42\%) were males \& 290 (58\%) were females indicating $16 \%$ higher prevalence of hypertension in female population. Mean age of male patients was $57.04 \pm 0.94$ years and female patients were $52.71 \pm 0.81$ years. The age difference between two gender groups ( $p \leq 0.1$ ) was statistically not significant.

Table 1- Demographic Profile of Patients

\begin{tabular}{lllll} 
GENDER & $\begin{array}{l}\text { NUMBER } \\
(\mathrm{n}=500)\end{array}$ & PERCENTAGE & $\begin{array}{l}\text { MEAN AGE } \pm \\
\text { S.E. }\end{array}$ & $\begin{array}{l}\text { P value } \\
(\mathrm{z} \text { test })\end{array}$ \\
\hline MALES & 210 & 42 & $57.04 \pm 0.94$ & 0.1 \\
FEMALES & 290 & 58 & $52.71 \pm 0.81$ & \\
\hline
\end{tabular}

Most of male hypertensive patients (43.3\%) were in the age group of $>60$ years \& most of female patients $(56.9 \%)$ were in the age group of 40 to 60 years indicating an earlier onset of hypertension in female population in our study group (Table 2).

Table 2- Age Group Distribution of Patients

\begin{tabular}{|c|c|c|c|c|c|c|}
\hline & & UPS & & & & \\
\hline & & & $40-$ & & & \\
\hline Category & Nur & ercentage & Nun & ercentage & Nur & ercentage \\
\hline Males & 29 & 13.81 & 90 & 42.86 & 91 & 43.33 \\
\hline Females & 57 & 19.65 & 165 & 56.9 & 68 & 23.45 \\
\hline
\end{tabular}

$15.8 \%$ of patients had diabetes mellitus $\& 3.8 \%$ had bronchial asthma as coexistent conditions (Table 3 ). The most frequently prescribed antihypertensive drug group was Angiotensin receptor blockers in diabetics $(56.25 \%)$ as well as asthmatics (68.42\%). None of the asthmatic hypertensive patient received beta blockers. Alpha adrenergic blockers \& central sympatholytics were also not prescribed to any of the diabetic or asthmatic patient with hypertension (Table 4).

Table 3- Comorbidities Of The Patients

\begin{tabular}{|c|c|c|c|c|}
\hline \multirow{2}{*}{ COMORBIDITY } & \multicolumn{2}{|c|}{ NUMBER } & \multirow{2}{*}{ TOTAL } & \multirow{2}{*}{ PERCENTAGE } \\
\hline & MALE & FEMALE & & \\
\hline DIABETES & 33 & 46 & 79 & 15.8 \\
\hline BRONCHIAL ASTHMA & 9 & 10 & 19 & 3.8 \\
\hline
\end{tabular}

Table 4- Treatment Of Hypertension In Diabetics and Asthmatics

\begin{tabular}{|c|c|c|c|c|c|c|c|}
\hline & \multicolumn{7}{|c|}{ PERCENTAGE OF PATIENTS } \\
\hline & ACEI & ARB & $\begin{array}{l}\text { Beta } \\
\text { Blocker }\end{array}$ & $\begin{array}{l}\text { Calium } \\
\text { Channel } \\
\text { Blocker }\end{array}$ & Diuretic: & $\begin{array}{l}\text { Alpha } \\
\text { s Adrenergic } \\
\text { Blockers }\end{array}$ & $\begin{array}{l}\text { Central } \\
\text { Sympatholyt- } \\
\text { ics }\end{array}$ \\
\hline & 21.25 & 56.25 & 28.75 & 18.75 & 51.25 & 0 & 0 \\
\hline Asthma & 15.79 & 68.42 & & 21.05 & 57.89 & 0 & 0 \\
\hline
\end{tabular}

Table 5- Frequency Of Administration Of Individual Drugs

\begin{tabular}{|c|c|c|}
\hline $\begin{array}{l}\text { ANTIHYPERTENSIVE } \\
\text { GROUP } \\
\text { DIURETICS }(53.4 \%)\end{array}$ & NAME OF DRUG & $\begin{array}{l}\text { NUMER OF } \\
\text { PRESCRIPTIONS }\end{array}$ \\
\hline & HYDROCHLOROTHIAZIDE & 106 \\
\hline & CHLORTHALIDONE & 2 \\
\hline & SPIRONOLACTONE & 55 \\
\hline & FUROSEMIDE & 23 \\
\hline & TORSEMIDE & 80 \\
\hline & METOLAZONE & 1 \\
\hline \multicolumn{3}{|l|}{ ARB ( 42.6\%) } \\
\hline & LOSARTAN & 55 \\
\hline & TELMISARTAN & 95 \\
\hline & OLMESARTAN & 63 \\
\hline \multicolumn{3}{|c|}{ BETA BLOCKER(38.6\%) } \\
\hline & METOPROLOL & 117 \\
\hline & ATENOLOL & 34 \\
\hline & PROPRANOLOL & 23 \\
\hline & NEIVOLOL & 12 \\
\hline & CARVEDILOL & 6 \\
\hline & BISOPROLOL & 1 \\
\hline \multicolumn{3}{|c|}{ CALCIUM CHANNEL BLOCKERS(26.4\%) } \\
\hline & AMLODIPINE & 113 \\
\hline & DILTIAZEM & 17 \\
\hline & NIFIDIPINE & 1 \\
\hline & NICARDIPINE & 1 \\
\hline \multicolumn{3}{|c|}{ ACE INHIBITOR ( $19.2 \%$ ) } \\
\hline & $\begin{array}{l}\text { RAMIPRIL } \\
\text { ENALAPRIL }\end{array}$ & $\begin{array}{l}86 \\
10\end{array}$ \\
\hline
\end{tabular}

Table 5 shows that diuretics was the most commonly prescribed group of antihypertensive drugs in $53.4 \%$ patients, followed by angiotensin receptor blockers in $42.6 \%$, beta blockers in $38.6 \%$ \& calcium channel blockers in $26.4 \%$ patients. Out of diuretics, thiazides group was the most commonly used $(40.4 \%)$.

Table 6 again shows diuretics to be the most commonly prescribed group of drugs in all the three age groups viz $<40$ years, $40-60$ years \& $>60$ years. $42.6 \%$ patients received monotherapy and rest $57.4 \%$ combination therapy. $37 \%$ of total patients received two 
drugs, $17.2 \%$ three drugs \& $3.2 \%$ received four or more drugs (Table 7).

Table 6- Antihypertensives Prescribed In Different Age Groups

\begin{tabular}{llllllll}
$\begin{array}{l}\text { Age } \\
\text { Group } \\
\text { (Years) }\end{array}$ & ACEI & ARB & $\begin{array}{l}\text { Beta } \\
\text { Blockers }\end{array}$ & $\begin{array}{l}\text { Calcium } \\
\text { Channel Diuretics } \\
\text { Blockers }\end{array}$ & \multicolumn{3}{c}{$\begin{array}{l}\text { Alpha } \\
\text { Adrener- } \\
\text { gic }\end{array}$} \\
Blockers & $\begin{array}{l}\text { Central } \\
\text { Sympa- } \\
\text { tholytics }\end{array}$ \\
\hline$<40^{\circ}$ & 16.28 & 34.88 & 40.69 & 26.74 & 44.19 & 0 & 2.33 \\
$40-60$ & 20 & 42.75 & 41.96 & 23.92 & 51.37 & 0.39 & 0 \\
$>60$ & 19.5 & 46.54 & 32.07 & 30.19 & 61.63 & 1.26 & 0 \\
\hline
\end{tabular}

Table 7- Number of Drugs Prescribed

\begin{tabular}{|lll|}
\hline Numer of antihypertensives & Number of prescriptions & Percentage \\
\hline One drug & 213 & 42.6 \\
Two drugs & 185 & 37 \\
Three drugs & 86 & 17.2 \\
Four Drugs or more & 16 & 3.2 \\
\hline
\end{tabular}

(Monotherapy Vs Combination Therapy)

FDCs are quite frequently used in treatment of hypertension. $41.6 \%$ of all prescriptions had FDCs (Table 8 ).

Table 8- Frequency of Prescribing FDC's

\begin{tabular}{|ll|}
\hline FDC's & NUMBER OF PRESCRIPTIONS \\
\hline Diuretics with ACE/ ARB, Beta blocker, CCB & 97 \\
Diuretics in combination & 40 \\
Beta Blocker + CCB & 35 \\
ACE Inhibitor/ ARB + CCB & 28 \\
3 drug FDC & 8 \\
ARB + CCB + Diuretic & \\
\hline
\end{tabular}

\section{Discussion}

Hypertension is a worldwide problem. Its prevalence depends upon several ethnic, genetic, environmental \& psychosocial factors. In India prevalence of hypertension (B.P. $\geq 140 / 90 \mathrm{~mm}$ of $\mathrm{Hg}$ ) is reported to be $25-30 \%$ in urban \& $10-15 \%$ in rural adults and it further increases with age. In elderly Indian population, a prevalence rate of $51.8 \%$ is reported [10]. Our study group also showed higher prevalence of hypertension in elderly patients ( $>40$ years). However, most females showed an earlier onset of hypertension than males. Main aim of antihypertensive therapy is to prevent hypertension related morbidity, mortality and complications. As antihypertensive prescription is required lifelong, therefore the side effects, quality of life and cost of drugs are also important aspects. Keeping all such factors in mind various prescribing guidelines have been formulated.

Guidelines given by Joint National Committee on prevalence, detection, evaluation and treatment of high blood pressure VIlth report suggest that treatment of choice for early stage, uncomplicated, essential hypertension should be thiazide diuretics. Presence of high risk conditions and blood pressure greater than 20/10 mm of $\mathrm{Hg}$ above normal is indication for starting therapy with drugs from other classes like ACE inhibitors, ARB's, beta blockers or calcium channel blockers alone or in combination with thiazides. Adherence to treatment guidelines can be monitored by several methods. Drug utilization studies are one such important method. Our data shows that JNC VII guidelines have been followed in totality in this study group. Thiazides are prescribed most frequently alone or in combination with other drugs. ARB's are the most frequently prescribed group in hypertensive diabetics and asthmatics as angiotensin antagonism is reported to decrease the onset \& progress of microvascular complications of hypertension and diabetes mellitus [11]. More than half $(57.4 \%)$ of patients in this study group received two or more antihypertensive drugs. FDCs have also been quite frequently used $(41.6 \%)$. This may be an attempt to improve patient compliance and reduce treatment costs. Such trend of multiple drug therapy in hypertension has also been reported in some other studies in India [6, 10].

Main limitation of drug utilization studies is the lack of detailed patient records for justifying the prescribed drugs based on grade of hypertension, presence of complications and previous drug therapy.

\author{
Abbreviations \\ Angiotensin converting enzyme inhibitors: ACE inhibitors \\ Angiotensin Receptor Blockers: ARBs \\ Calcium Channel Blockers: CCBs \\ Fixed Dose Combinations: FDCs \\ Blood Pressure: BP
}

\section{References}

[1] Kearney P.M., Whelton M., Reynolds K., Muntner P., Whelton P.K. and He J. (2005) Lancet 217- 223.

[2] Lawes C.M., Vander Hoorn S., Law M.R., Elliott P., Mac Mahon S. and Rodgers A. (2006) J. Hypertens, 24, 423-430.

[3] World Health Organization (WHO) International Society of $\mathrm{Hy}$ pertension (ISH). (2003) J. Hypertens., 21, 1983-1992.

[4] Blood Pressure Lowering Treatment Trialists' Collaboration. (2000) Lancet, 356, 1955-1964.

[5] Staessen J.A., Wang J.G. and Thijs L. (2001) Lancet, 358, 1305-1315.

[6] Xavier D., Mathew N., Pradeep J. and Pais P. (2001) Indian J. Pharmacology, 33, 456-457.

[7] Avanzini F., Corsetti A. and Maglione T. (2002) Am. Heart J., 144(4), 726-732.

[8] Chobanian A.V., Bakris G.L., Black H.R., Cushman W.C., Green L.A., Izzo J.L. Jr., Jones D.W., Materson B.J., Oparil S., Wright J.T. Jr. and Roccella E.J. (2003) JAMA, 21, 289, 256072.

[9] Gupta N., Sharma D., Garg S.K. and Bhargava V.K. (1997) Indian J. Pharmacol., 29, 411-415.

[10]Augustine L., Prasanth N.V., Sanal Dev K.T., Jasmin S., Kappekkat Y., Shinu C. and Thayyil A. (2010) Der. Pharma Chemica., 2(6), 332-341.

[11]European Society of Hypertension-European Society of Cardiology Guidelines Committee. (2003) J. Hypertens., 21(6), 101153. 